\title{
PENGARUH EUTROFIKASI TERHADAP KUALITAS AIR DI SUNGAI JENEBERANG
}

\section{EFFECT OF EUTROPHICATION ON WATER QUALITY IN JENEBERANG RIVER}

\author{
Andi Nur Afia Alfionita1), Patang 2), Ernawati S.Kaseng3) \\ ${ }^{1}$ Alumni Program Studi Pendidikan Teknologi Pertanian \\ ${ }^{2}$ dan ${ }^{3}$ Dosen PTP FT UNM \\ andinurafia85@gmail.com
}

\begin{abstract}
ABSTRAK
\end{abstract}
Sungai merupakan salah satu sumber daya alam yang bermanfaat bagi kehidupan manusia, seperti dalam bidang pertanian dan proses budidaya perikanan khususnya di Sungai Jneberang. Sepanjang aliran Sungai Jeneberang terdapat area pesrsawahan, pertambangan dan pemukiman penduduk yang menyebabkan masuknya bahan organik ke badan aliran sungai. Tujuan dari penelitian ini adalah untuk mengetahui tingkat eurofikasi yang terjadi di Sunagai Jeneberang dan juga untuk mengetahui pengaruh eutrofikasi terhapdap kualitas air di sungai tersebut. Penelitian ini merupakan jenis penelitian deskriktif dengan menggunakan metode survei, penelitian ini dilakukan dengan mengambil sampel air pada lima stasiun yakni, daerah hulu, tengah dan hilir. Hasil penelitian menunjukkan bahwa eutrofikasi telah terjadi di Sungai Jenebrang dan berada pada status hipertrofik. Selain itu, dari hasil uji regresi diperoleh bahwa eutrofikasi berpengaruh nyata terhadap kandungan oksigen terlarut dan $\mathrm{pH}$ pada sungai Jeneberang. Namun, eutrofikasi tidak berpengaruh nyata terhadap kelimpahan plankton, dan suhu.

Kata Kunci: Eutrofikasi, pH, suhu, oksigen terlarut, plankton.

\section{ABSTRACT}

The river is one of the natural resources that are beneficial to human life, such as in agriculture and aquaculture processes, particulary in the Jeneberang River. Along the Jeneberang River flow, be found a rice fields area, mining and resident settlements which causes the entry of organic matter into river flow bodies. The purpose of this study was to determine the level of eurofication that occurred in the Jeneberang River and also to determine the effect of eutrophication on water quality in that river. This research was descriptive research using survey methods, this research was carried out by taking water samples at five stations namely, upstream, middle and downstream. The results showed that eutrophication had occurred in the Jenebrang River and was at the hypertrophic status. In addition, the results of the regression test showed that eutrophication had a significant take effect on dissolved oxygen content and $\mathrm{Ph}$ on the Jeneberang river. However, eutrophication does no significant effect on abundance plankton, and temperature.

Keywords : Eeutrophication, pH, temperature, dissolved oxygen, plankton

\section{PENDAHULUAN}

Sungai merupakan aliran air yang memanjang dan mengalir terus menerus dari hulu menuju hilir. Hulu sungai adalah bagian tertinggi dari alur sungai dan merupakan awal sumber air masuk ke dalam sungai, sedangkan hilir merupakan bagian alur sungai terendah dan paling dekat dengan muara. Sungai menjadi ekosistem yang penting bagi kehidupan manusia, hewan dan tumbuhan. Sungai dapat dimanfaatkan sebagai sarana transportasi dan air sungai juga dapat dimanfaatkan dalam berbagai bidang seperti pertanian, industri maupun domestik. Dalam sungai terdapat berbagai jenis biota air yang sangat dibutuhkan oleh manusia seperti ikan. Pertumbuhan biota air tersebut sangat 
ditentukan oleh kualitas air dan ketersediaan pakan didalamnya. Namun, stabilitas ekosistem di sungai dapat rusak akibat beberapa faktor diantaranya adalah aktivitas manusia sebagai penggunanya yang dapat membuat sungai tersebut tercemar.

Peningkatan aktivitas manusia pada daerah aliran sungai dikhawatirkan akan membawa dampak negatif bagi keseimbangan ekosistem yang ada di sungai. Hal ini disebabkan seiring pertumbuhan penduduk yang semakin pesat dan banyaknya aktivitas manusia yang membuang limbahnya ke sungai. Pencemaran dan sedimentasi tinggi akibat suplai dari daerah aliran sungai terutama oleh aktifitas penambangan, pertanian maupun oleh limbah rumah tangga (Ayyub, et al., 2018).

Salah satu sungai yang terdapat di Sulawesi Selatan yaitu Sungai Jeneberang. Sungai ini terdapat di Kabupaten Gowa dengan hulu terdapat di daerah Bili-Bili dan bermuara di laut lepas yakni Tanjung Bayang. Sepanjang aliran Sungai Jeneberang terdapat rumah pemukiman dan banyak aktivitas manusia yang tentunya menghasilkan limbah dan dibuang langsung di sungai. Khususnya di daerah hulu sungai tersebut, terdapat area persawahan yang dalam usaha budidaya menggunakan bahan kimia yang akan menghasilkan limbah. Lahan pertanian tersebut menggunakan pemupukan yang berat sehingga ketika sebagian dari pupuk ini tercuci oleh air hujan maka air limbah pertanian tersebut masuk ke dalam badan air. Tentunya hal tersebut akan menyumbangkan limbah atau residu kimia ke sungai dan dapat berdampak pada kualitas airnya. Menurut Patang (2014), kualitas air dapat secara luas didefinisikan sebagai faktor-faktor fisik, yang mempengaruhi penggunaan air kimia dan biologis untuk dimanfaatkan oleh manusia baik secara langsung maupun tidak langsung.

Selain di daerah hulu, aktivitas manusia juga berlangsung di sepanjang sungai terutama di daerah pemukiman. Limbah pemukiman ada yang langsung dialirkan ke sungai sehingga juga dapat memberikan dampak negatif terhadap kualitas air sungai. Aktivitas masyarakat sehari-hari dapat menyebabkan masuknya bahan pencemar. Menurut Alamsyah (1999) dalam Patang (2009) pencemaran lingkungan pesisir dan laut dapat diakibatkan oleh limbah buangan kegiatan tau aktivitas di daratan (land based pollution) maupun kegiatan atau aktivitas di lautan (Sea based poluution)

Masukan bahan organik yang terbawa melalui limbah yang dihasilkan oleh kegiatan manusia akan masuk ke perairan dan pada kondisi tertentu akan mengganggu existing perairan. Kandungan bahan organik yang terlalu tinggi akan menyebabkan perairan mengalami eutrofikasi. Eutrofikasi ialah pencemaran air yang disebabkan oleh munculnya nutrient yang berlebihan ke dalam ekosistem air yang berakibat tidak terkontrolnya pertumbuhan tumbuhan air (Simbolon, 2016). Peningkatan kadar bahan organik ditandai dengan terjadinya peningkatan fitoplankton dan tumbuhnya air yang meningkat (blooming algae).

Bahan organik dan senyawa nutrisi yang muncul dalam badan air kemudian didekomposisi oleh bakteri menggunakan oksigen terlarut untuk proses biokimia maupun proses biodegradasi. Hal ini akan mengakibatkan penurunan kadar oksigen terlarut dalam badan air. Oksigen 
merupakan gas tak berbau, tak berasa dan hanya sedikit terdapat dalam air. Untuk mempertahankan hidupnya, makhluk yang tinggal di dalam air baik hewan maupun tumbuhan bergantung pada oksigen terlarut ini. Oksigen dibutuhkan untuk pernapasan dan proses metabolisme. Eutrofikasi juga dikhawatirkan akan meningkatkan kandungan amonia yang bersifat toksik bagi biota air. Aktivitas manusia di daerah aliran Sungai Jeneberang telah berlangsung cukup lama, sehingga diindikasikan air sungai tersebut telah mengalami pencemaran terutama disebabkan air limbah domestik, industri dan pertanian.

Perubahan tatahguna lahan ditandai dengan meningkatnya aktivitas domestik, pertanian dan industri akan mempengaruhi kualitas air sungai terutama limbah domestik. Telah dilakukan beberapa penelitian pada sungai Jeneberang.

Dari beberapa penelitian yang telah dilakukan, selain waktu penelitian yang sudah lama juga belum ada yang mengkaji tentang eutrofikasi. Oleh karena itu, pada penelitian ini mencoba untuk mengkaji pengaruh eutrofikasi terhadap kualitas air di sungai Jeneberang.

\section{Tujuan Penelitian}

Tujuan yang ingin dicapai dalam penelitian ini adalah untuk menganalisis adanya eutrofikasi di Sungai Jeneberang, untuk menegetahui kualitas air Sungai Jeneberang dan untuk mengetahui pengaruh eutrofikasi terhadap kualitas air di Sungai Jeneberang

\section{METODE PENELTIAN}

Jenis penelitian ini adalah penelitian deskriptif dengan menggunakan metode survei yang bertujuan untuk mengetahui pengaruh eutrofikasi terhadap kualitas air di Sungai Jeneberang. Lokasi pengambilan sampel air di Sungai Jeneberang dapat dilihat pada Gambar 1.

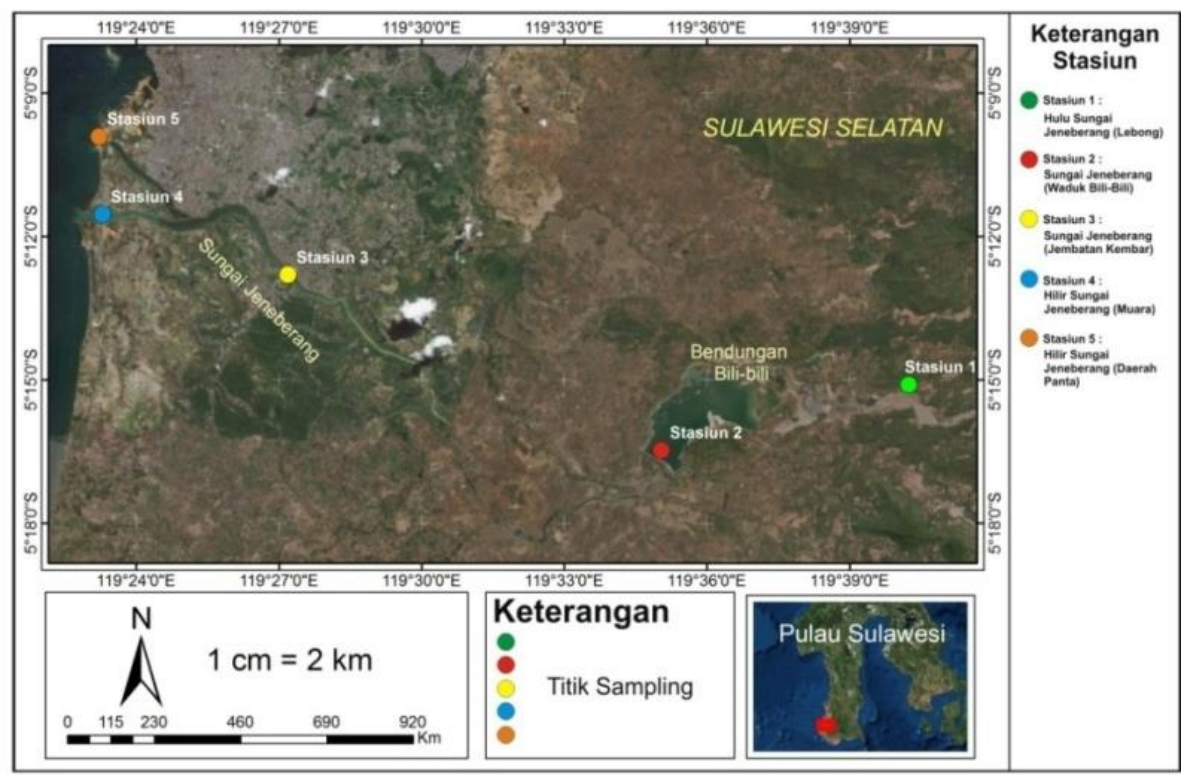

Gambar 1 Stasiun Pengambilan Sampel

Pengambilan sampel dilakukan pada

lima stasiun yakni: 
1. Titik pengambilan sampel stasiun 1 yaitu di bagian hulu Sungai Jeneberang tepatnya di daerah Lebong

2. Titik pengambilan sampel Stasiun 2 yaitu di bagian Sungai Jeneberang tepatnya di Waduk Bili Bili

3. Titik pengambilan sampel Stasiun 3 yaitu di bagian Sungai Jeneberang tepatnya di Jembatan Kembar.

4. Titik pengambilan sampel Stasiun 4 yaitu di bagian hilir Sungai Jenebrang tepatnya di muara.

5. Titik pengambilan sampel Stasiun 5 yaitu di bagian hilir sungai Jenebrang tepatnya di daerah pantai.

Pengambilan sampel dilakukan sebanyak lima kali pada masing-masing stasiun dengan interval waktu satu minggu. Data yang digunakan dalam penelitian ini adalah data primer yang diambil secara langsung di lokasi, dan data sekunder yang dikumpukan dari berbagai hasil penelitian.

\section{Status Eutrofikasi Sungai Jeneberang}

Sungai Jeneberang merupakan salah satu jenis sungai yang terletak di Sulawesi Selatan yakni Kabupaten Gowa. Banyaknya aktivitas di sepanjang aliran sungai, menyebabkan terjadinya eutrofikasi. Pada umumnya aktivitas manusia yang ada di sekitar Sungai Jeneberang yaitu terdapat area persawahan, industri, pertambangan dan aktivitas rumah tangga yang buangannya langsung dialirkan ke sungai. Eutrofikasi adalah masuknya bahan organik dalam badan air sehingga meningkatkan kesuburan. Salah satu cara penentuan tingkat eutrofikasi dalam suatu perairan yakni dengan melakukan pengukuran Nitrogen total dan Fosfat perairan tersebut.

\section{Kandungan Nitrogen Total}

Kandungan Nitrogen ,ang diperoleh dari hasil pengujian di Sungai Jeneberang berkisar antara 85,498 mg/L sampai dengan $109.008 \mathrm{mg} / \mathrm{L}$ dapat dilihat pada Gambar 2.

\section{HASIL DAN PEMBAHASAN}

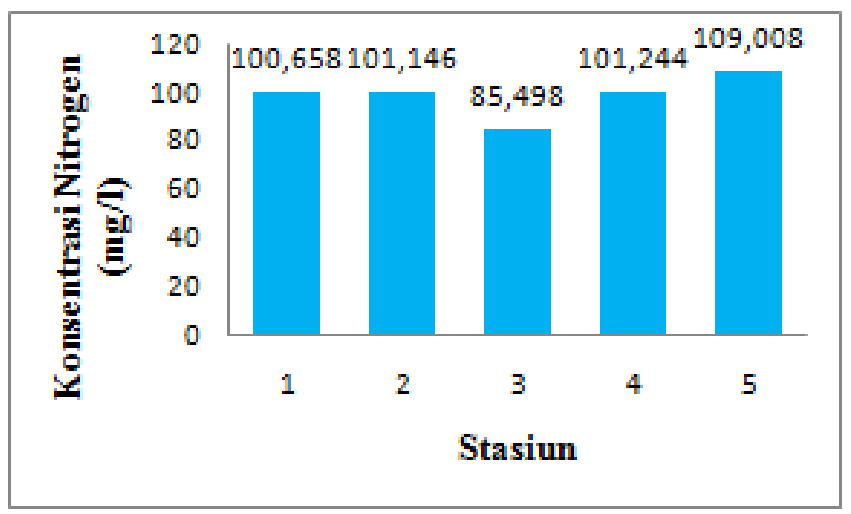

Gambar 2. Rata-rata kandungan Nitrogen setiap stasiun Sungai Jeneberang

Berdasarkan Gambar 2, nilai rata-rata $\mathrm{N}$ total tertinggi di Sungai Jeneberang yaitu pada Stasiun 5 yakni $109.008 \mathrm{mg} / \mathrm{L}$. Tingginya kadar $\mathrm{N}$ total pada Stasiun 5 disebabkan beberapa faktor, salah satu faktor yang sangat mempengaruhi yakni adanya sisa pakan dari budidaya, daerah hilir terdapat banyaknya pemukiman penduduk dan terakumulasinya kandungan Nitrogen yang mengalir dari hulu sungai Jeneberang. Berdasarkan observasi langsung, pada stasiun 5 terdapat beberapa 
budidaya keramba jaring apung yang tentunya dalam proses budidayanya menggunakan pakan buatan. Price dan Morris (2013) dalam Putri, Widyastuti dan Christiani (2014), menyatakan bahwa KJA memberikan kontribusi Nitrogen di perairan yaitu dalam betuk sisa pakan yang tidak dimakan ikan, feses ikan, dan limbah metabolik ikan berupa amonia juga urea.

Pakan yang diberikan kepada ikan mengandung sekitar 68\%-86\% N dilepaskan ke lingkungan perairan dan sisanya dimakan oleh ikan (Price dan Morris, (2013) dalam Putri, Widyastuti dan Christiani, 2014). Kandungan $\mathrm{N}$ total terendah terdapat pada analisis Kandungan $\mathrm{N}$ total di Sungai Jeneberang dengan menggunakan 5 stasiun pengambilan sampel, pada umumnya diperoleh kandungan $\mathrm{N}$ total yang tinggi yakni $85,498 \mathrm{mg} \mathrm{L}^{-1}$ - 109,008 mg L-1. Limbah pakan ikan juga menimbulkan pencemaran perairan serta meningkatnya kadar $\mathrm{N}$ dan $\mathrm{P}$ yang pada akhirnya terjadi eutrofikasi (penyuburan).

\section{Kandungan Fosfat}

Kandungan Fosfat yang diperoleh dari hasil pengujian di Sungai Jeneberang berkisar antara 0,878 $\mathrm{mg} / \mathrm{L}$ sampai dengan $1,473 \mathrm{mg} / \mathrm{L}$ dapat dilihat pada Gambar 3.

Stasiun 3. Namun, berdasarkan hasil

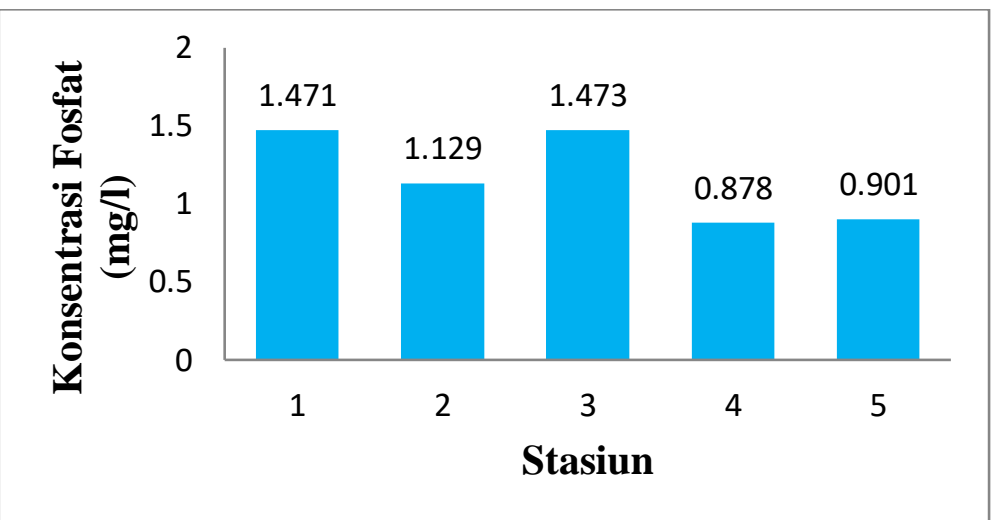

Gambar 3. Rata-rata kandungan Fosfat setiap stasiun Sungai Jeneberang

Berdasarkan Gambar 3, pada umumnya kandungan Fosfat di setiap stasiun pengambilan sampel tinggi. Kandungan Fosfat paling tinggi ke terendah berturut-turut, Stasiun $3(1,473 \mathrm{mg} \mathrm{L}-1)$, Stasiun $1\left(1,471 \mathrm{mg} \mathrm{L}^{-1}\right)$, Stasiun $2(1,129$ $\left.\mathrm{mg} \mathrm{L}^{-1}\right)$, Stasiun $5\left(0,901 \mathrm{mg} \mathrm{L}^{-1}\right)$ dan Stasiun $4 \quad\left(0,878 \quad \mathrm{mg} \mathrm{L}^{-1}\right)$. Tingginya kandungan Fosfat di Stasiun 3 disebabkan karena sepanjang aliran sungai menuju Stasiun 3 terdapat tambang pasir, industri pengolahan air dan limbah rumah tangga yang buangannya langsung dialirkan ke badan sungai.
Menurut Sastrawijaya (2000) dalam Silalahi (2009), Fosfat dan Nitrogen merupakan unsur pembatas dalam proses eutrofikasi. Oleh karena itu, sungai Jeneberang memiliki tingkat kesuburan yang tinggi atau terjadi eutrofikasi berdasarkan hasil pengukuran Nitrogen Total dan Fosfat . Hal ini didasarkan tingkatan trofik yang dikemukakan oleh Brahmana dan Firdaus (2012) tingkat eutrofikasi yang terjadi pada suatu perairan biasanya dinyatakan dengan status trofik

Kandungan Fosfat di perairan Sungai Jeneberang tergolong tinggi dengan ratarata $0,878 \mathrm{mg} \mathrm{L}^{-1}$ sampai dengan $1,473 \mathrm{mg}$ 
$\mathrm{L}^{-1}$. Kandungan Fosfat dalam air merupakan karakteristik kesuburan perairan yang bersangkutan. Tingginya kandungan Fosfat di Sungai Jeneberang umumnya disebabkan karena banyaknya unsur hara yang masuk ke dalam badan sungai yang berasal dari pemukiman, industri, area persawahan dan peternakan masyarakat. Pada umumnya perairan yang mengandung Fosfat antara 0,03-0,1 $\mathrm{mg} \mathrm{L}^{-1}$ adalah perairan yang oligotrofik. Kandungan antara 0,11 -0,3 mg $\mathrm{L}^{-1}$ perairan yang mesotrofik dan kandungan antara $0,31-1,0 \mathrm{mg} \mathrm{L}^{-1}$ adalah perairan eutrofik (Hidayat, 2001). Sejalan dengan peneltian Hariani (2013) menunjukkan bahwa berdasarkan kandungan Fosfat di setiap stasiun menunjukkan bahwa status perairan waduk saguling adalah eutrofik karena berada pada kisaran $0,035-0,1 \mathrm{mg}$ $\mathrm{L}^{-1}$.

Sama halnya dengan nutrien yang lain, Fosfat di perairan sangat dimungkinkan berasal dari daratan. Sumber utama Fosfat adalah pemupukan dari kegiatan pertanian dan pertambakan, limbah industri atau bahkan limbah rumah tangga.

\section{Kualitas Air dan Pengaruh Eutrofikasi terhadap Kualitas Air \\ pH}

Hasil pengukuran $\mathrm{pH}$ pada aliran Sungai Jeneberang berkisar antara 6,28 sampai dengan 7,98 dapat dilihat pada Gambar 4.

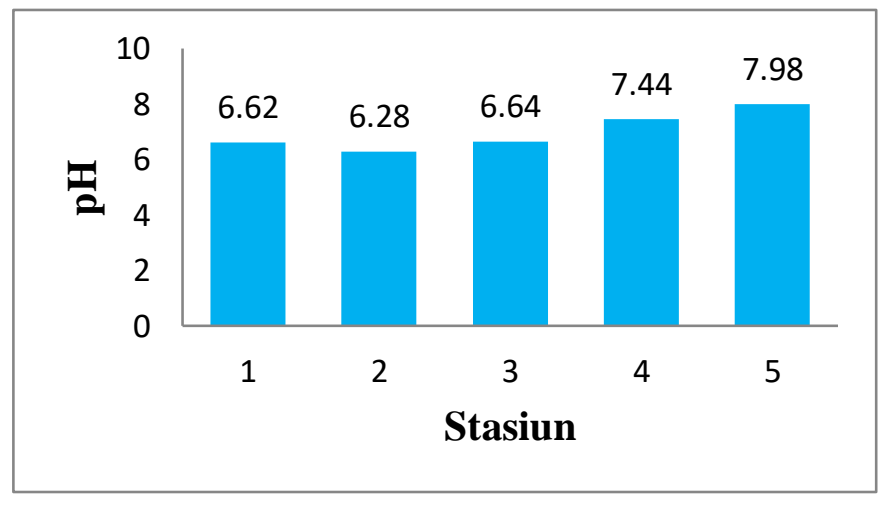

Gambar 4. Rata-rata kandungan pH setiap stasiun Sungai Jeneberang

Hasil uji regersi berganda pengaruh eutrofikasi yakni Nitrogen total dan Fosfat secara simultan terhadap $\mathrm{pH}$ di Sungai Jeneberang dapat dilihat pada Tebel 1.

Tabel 1 Nilai koefisien regeresi, korelasi, koefesien determinan dan uji regresi

\begin{tabular}{|c|c|c|c|c|c|c|}
\hline \multirow{2}{*}{ Variabel } & \multirow{2}{*}{$\begin{array}{l}\text { Koefesien } \\
\text { Regeresi }\end{array}$} & \multirow{2}{*}{$\mathrm{R}$} & \multirow{2}{*}{$R^{2}$} & \multirow{2}{*}{ F Hitung } & \multicolumn{2}{|c|}{ F Tabel } \\
\hline & & & & & $5 \%$ & $1 \%$ \\
\hline Kostanta & 6,709 & \multirow{3}{*}{0,593} & \multirow{3}{*}{0,352} & \multirow{3}{*}{5,967} & \multirow{3}{*}{3,44} & \multirow{3}{*}{5,719} \\
\hline$X_{1}$ & 0,012 & & & & & \\
\hline$X_{2}$ & $-0,778$ & & & & & \\
\hline
\end{tabular}

Sumber: Hasil Analisis Data Penelitian, 2018

Persamaan regresi $\mathrm{pH}$ pada Sungai Jeneberang yaitu:

$y=6,709+0,012 X_{1}-0,778 X_{2}$
Nilai $\mathrm{pH}$ setiap stasiun pada sungai Jeneberang berdasarkan pengamatan setiap minggunya yakni berkisar antara 6 - 
8. Kondisi ini dapat dikatakan baik karena masih berada dalam kisaran baku mutu air kelas II. Berdasarkan Peraturan Pemerintah Republik Indonesia Nomor 82 Tahun 2001, $\mathrm{pH}$ air yang masuk kategori kelas II yaitu 6-9 artinya kualitas air tersebut dapat digunakan untuk prasarana/sarana rekreasi air, pembudidayaan ikan air tawar, peternakan, air untuk mengairi pertanaman, dan atau peruntukan lain yang mempersyaratkan mutu air yang sama dengan kegunaan tersebut.

Kandungan $\mathrm{pH}$ tertinggi diperoleh pada Stasiun 5 dengan nilai 7,98. Tingginya derajat keasaman pada Stasiun 5 diduga karena adanya kotoran organisme air terutama kotoran ikan yang dibudidayakan dalam keramba jaring apung dan buangan dari pemukiman dan industri rumah tangga yang ada di daerah sekitar aliran sungai Jeneberang. Menurut Connel (1995), nilai $\mathrm{pH}$ dapat dipengaruhi oleh kotoran organisme air yang mengandung ammonia yang dapat meningkatkan derajat keasaman (pH) yakni menjadi basa. Perairan yang memiliki kadar $\mathrm{pH}$ ideal bagi kehidupan organisme akuatik pada umumnya berkisar antara 7 sampai 8,5. Kondisi perairan yang asam akan membahayakan kelangsungan hidup organisme karena menyebabkan terjadinya berbagai gangguan seperti gangguan metabolisme dan respirasi, termasuk pada benthos (Barus, 2004). Selain itu pada lokasi ini yaitu daerah muara yang memiliki salinitas atau kadar garam yang lebih tinggi dibandingkan dengan daerah sungai. Hal ini sejalan dengan pendapat Susana (2009) bahwa kenaikan $\mathrm{pH}$ yang terjadi dari arah sungai ke arah laut disebabkan terjadinya pencampuran antara air tawar bersalinitas rendah yang berasal dari daratan dengan air laut yang bersalinitas lebih tinggi. Menurut Nurdin (2009) dalam Wanna, et al. (2017) pada umumnya nilai $\mathrm{pH}$ di perairan rendah bersamaan dengan rendahnya kandungan mineral yang ada atau sebaliknya.

Berdasarkan uji regresi berganda hubungan Eutrofikasi dengan $\mathrm{pH}$ di Sungai Jeneberang diperoleh $\mathrm{F}$ hitung lebih besar dari $\mathrm{F}$ tabel $1 \%$. Hal ini menunjukkan bahwa eutrofikasi memberikan pengaruh sangat nyata terhadap $\mathrm{pH}$. Koefesien korelasi (R) pada Sungai Jeneberang yaitu 0,593 menunjukkan hubungan variabel bebas $(X)$ terhadap ( $\mathrm{Y}$ ) adalah positif sedang karena lebih dari 0,5 . Koefesien determinan $\left(R^{2}\right)=$ 0,352 menunjukkan ketepatan model tersebut baik karena mendekati $50 \%$, diartikan bahwa pengaruh eutrofikasi yang merupakan variabel bebas terhadap $\mathrm{pH}$ di Sungai Jeneberang yaitu sebesar 35,2 \% dan sisanya sebesar $64,8 \%$ ditentukan oleh faktor-faktor lain yang tidak digunakan dalam analisis ini.

\section{Oksigen Terlarut (DO)}

Hasil pengukuran oksigen terlarut pada aliran Sungai Jeneberang berkisar antara 5,4 mg/L samapi dengan 6,84 mg/L dapat dilihat pada Gambar 5 . 


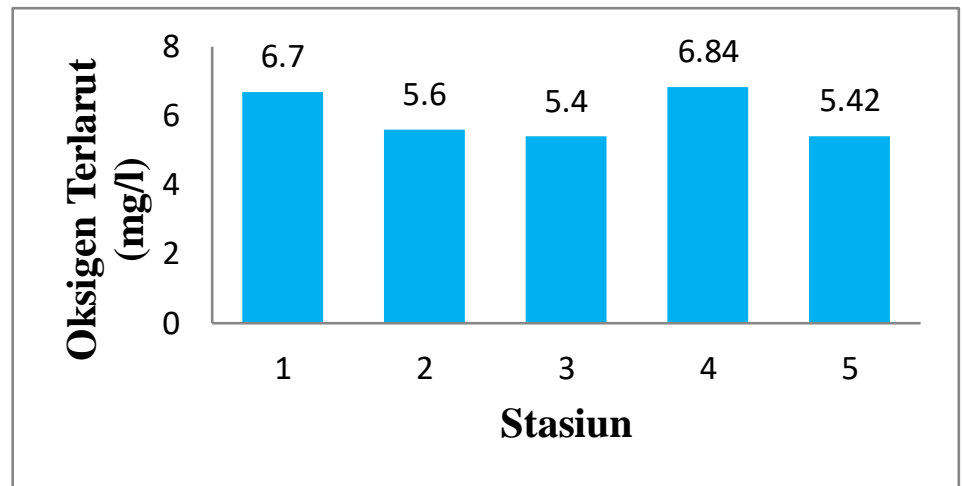

Gambar 5. Rata-rata kandungan oksigen terlarut setiap stasiun Sungai Jeneberang

Hasil uji regersi berganda pengaruh eutrofikasi yakni Nitrogen total dan Fosfat secara simultan terhadap oksigen terlarut di
Sungai Jeneberang dapat dilihat pada Tabel 2.

Tabel 2 Nilai koefisien regeresi, korelasi, koefesien determinan dan uji regresi

\begin{tabular}{|c|r|c|c|c|c|c|}
\hline \multirow{2}{*}{ Variabel } & $\begin{array}{r}\text { Koefesien } \\
\text { Regeresi }\end{array}$ & \multirow{2}{*}{$\mathrm{R}$} & \multirow{2}{*}{$\mathrm{R}^{2}$} & \multirow{2}{*}{$\mathrm{F}$ Hitung } & \multicolumn{2}{|c|}{$\mathrm{F} \mathrm{Tabel}$} \\
\cline { 1 - 1 } Kostanta & 4,242 & & & & & \\
\hline $\mathrm{X}_{1}$ & 0,018 & 0,529 & 0,280 & 4,274 & 3,44 & 5,719 \\
\hline $\mathrm{X}_{2}$ & 0,004 & & & & & \\
\hline
\end{tabular}

Sumber: Hasil Analisis Data Penelitian, 2018

Persamaan regresi oksigen terlarut pada Sungai Jeneberang yaitu: $y=4,242+0,018 X_{1}+0,004 X_{2}$

Oksigen terlarut atau dissolved oxygen (DO) merupakan variabel kualitas air yang sangat penting dalam kegiatan budidaya. Semua organisme akuatik membutuhkan oksigen terlarut untuk metabolisme. Berdasarkan hasil regresi menunjukkan adanya pengaruh eutrofikasi terhadap oksigen terlarut, serta berdasarkan gambar Gambar 5 dapat dilihat bahwa konsentrasi oksigen teralarut tertinggi di Sungai Jeneberang terdapat pada Stasiun 4 yakni 6,84 .

Tingginya kandungan oksigen terlarut pada Stasiun 4 disebabkan karena pada lokasi ini pertemuan antara air laut atau muara sehingga air pada perairan tersebut cukup jernih, pendapat ini sejalan dengan pendapat Patty (2013) mengemukakan bahwa tingginya kadar oksigen terlarut $\mathrm{di}$ perairan lepas pantai, dikarenakan airnya jernih sehingga dengan lancarnya oksigen yang masuk kedalam air tanpa hambatan melalui proses difusi dan proses fotosintesis. Kandungan oksigen terlarut terendah diperoleh pada Stasiun 3 yakni 5,4 $\mathrm{mgL}^{-1}$. Redahnya oksigen terlarut pada Stasiun 3 dikerenakan pada daerah ini terdapat berbagai industri dan dekat dengan pemukiman warga yang dapat memberikan masukan bahan organik sehingga dibutuhkan banyak oksigen untuk mengurai bahan organik tersebut baik secara kimiawi maupun biologis.

Menurut Patty (2013) bahwa limbahlimbah dan kotoran yang berasal dari 
darat masuk ke peraiaran melalui aliranaliran air tawar. Dengan demikian banyak oksigen yang diperlukan untuk penguraiannya, baik secara biologis maupun kimiawi. Menurut Yuliastuti (2011) bahwa rendah dan menurunnya konsentrasi oksigen terlarut mengindikasikan terjadinya pencemaran bahan-bahan organik terutama oleh air limbah domestik terutama didaerah pemukiman dan aktivitas peternakan. Rendahnya kisaran DO tersebut merupakan indikasi kuat telah terjadi pencemaran yang diduga disebabkan limbah pemukiman dan berpotensi menyebabkan pencemaran.

Hasil pengurkuran DO dari hulu ke hilir sungai Jeneberang pada masingmasing stasiun berdasrkan hasil pengamatan setiap minggunya berkisar antara 5,4-6,84 $\mathrm{mg} \mathrm{L}^{-1}$ yang artinya masih dalam kondisi normal. Dan masih memenuhu syarat baku mutu air kelas II PP NO. 82 Tahun 2001. Sejalan dengan pendapat Kristanto (2004) bahwa kehidupan di air dapat bertahan jika terdapat oksigen terlarut minimal sebanyak 5 ppm atau $5 \mathrm{mg}$ $\mathrm{L}^{-1}$, selebihnya bergantung kepada ketahanan organisme, derajat aktif, kehadiran bahan pencemar dan suhu air. Novotny dan Olem (1994) dalam Effendi (2003) menyatakan bahwa sumber oksigen terlarut dapat berasal dari difusi oksigen yang terdapat di atmosfer.

Oksigen terlarut juga berasal dari aktivitas fotosintesis oleh tumbuhan air dan fitoplankton. Pada saat cuaca mendung atau hujan dapat menghambat pertumbuhan fitoplankton, karena kekurangan sinar matahari untuk proses fotosintesis. Kondisi ini akan menyebabkan penurunan kadar oksigen terlarut karena oksigen tidak dapat diproduksi, sementara organisme akuatik tetap mengkonsumsi oksigen.

Fardiaz (1992) dalam Nur, et al (2016), menyatakan bahwa kejenuhan oksigen dalam air dipengaruhi oleh suhu air, semakin tinggi suhu maka konsentrasi oksigen terlarut semakin turun.

Berdasarkan uji regresi berganda hubungan Eutrofikasi dengan oksigen terlarut (DO) di Sungai Jeneberang diperoleh $\mathrm{F}$ hitung lebih besar dari $\mathrm{F}$ tabel $5 \%$. Hal ini menunjukkan bahwa eutrofikasi memberikan pengaruh nyata terhadap oksigen terlarut. Koefesien korelasi (R) pada Sungai Jeneberang yaitu 0,529 menunjukkan hubungan variabel bebas $(X)$ terhadap ( $\mathrm{Y})$ adalah positif sedang. Koefesien determinan $\left(R^{2}\right)=0,280$ menunjukkan ketepatan model tersebut baik karena mendekati $50 \%$, diartikan bahwa pengaruh eutrofikasi yang merupakan variabel bebas terhadap oksigen terlarut di Sungai Jeneberang yaitu sebesar $28,0 \%$ dan sisanya sebesar 72,0 \% ditentukan oleh faktor-faktor lain yang tidak digunakan dalam analisis ini. Dengan demikian, model ini sangat dapat digunakan dalam pendugaan pengaruh eutrofikasi terhadap kualitas air khusunya oksigen terlarut dalam sebuah perairan.

\section{Suhu}

Hasil pengukuran suhu pada aliran Sungai Jeneberang berkisar antara $24{ }^{\circ} \mathrm{C}$ sampai dengan $29,8^{\circ} \mathrm{C}$ dapat dilihat pada Gambar 6. 


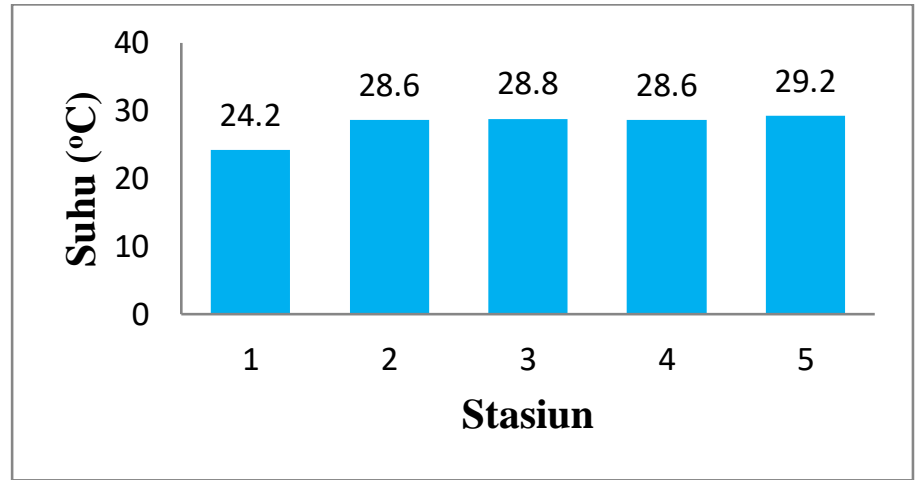

Gambar 6. Rata-rata suhu setiap stasiun Sungai Jeneberang

Hasil uji regersi berganda pengaruh eutrofikasi yakni Nitrogen total dan Fosfat secara simultan terhadap suhu di Sungai Jeneberang dapat dilihat pada Tebel 3.

Tabel 3 Nilai koefisien regeresi, korelasi, koefesien determinan dan uji regresi

\begin{tabular}{|c|r|c|c|c|c|c|}
\hline Variabel & $\begin{array}{r}\text { Koefesien } \\
\text { Regeresi }\end{array}$ & \multirow{2}{*}{$\mathrm{R}$} & \multirow{2}{*}{$\mathrm{R}^{2}$} & \multirow{2}{*}{$\mathrm{F}$ Hitung } & \multicolumn{2}{|c|}{$\mathrm{F}$ Tabel } \\
\hline Kostanta & 28,621 & & & & & \\
\hline$X_{1}$ & 0,010 & 0,319 & 0,102 & 1,243 & 3,44 & 5,719 \\
\hline$X_{2}$ & $-1,447$ & & & & & \\
\hline
\end{tabular}

Sumber: Hasil Analisis Data Penelitian, 2018

Persamaan regresi suhu pada Sungai Jeneberang yaitu:

$y=28,621+0,010 X_{1}-1,447 X_{2}$

Berdasarkan hasil pengamatan suhu yang disajikan pada Gambar 6 dapat dilihat bahwa suhu disetiap stasiun pengambilan sampel di Sungai Jeneberang disetiap minggunya masuk kategori normal suhu perairan yakni berkisar $24-30^{\circ} \mathrm{C}$. Suhu ini masih di atas kisaran suhu air di perairan laut, dimana nilai suhu di lapisan permukaan laut yang normal berkisar antara $20-30^{\circ} \mathrm{C}$ (Nybakken, 1988). Menurut Nontji (2002) dalam Trisna et al., (2001), suhu air permukaan di perairan Indonesia pada umumnya berkisar antara $28-31^{\circ} \mathrm{C}$. Suhu terendah terdapat pada Stasiun 1 yakni berkisar $24{ }^{\circ} \mathrm{C}$, hal ini dikarenakan pada lokasi pengambilan sampel di daerah pegunungan dan waktu pengambilan sampel pada pagi hari.
Suhu tertinggi terdapat pada Stasiun 4 dan 5, hal ini dikarenakan waktu pengamatan dilakukan pada pukul 10.00 WITA. Faktor kedalaman juga menjadi penyebab berbedanya suhu di setiap stasiun. Suhu menurun seiring dengan meningkatnya kedalaman pada setiap stasiun dan waktu pengamatan. Officer (1976) mengemukakan bahwa kondisi suhu air di suatu perairan di pengaruhi terutama oleh kondisi atmosfir, cuaca dan intensitas matahari yang masuk ke laut. Kecenderungan suhu air yang demikian disebabkan adanya perbedaan intensitas cahaya matahari yang mampu diserap pada setiap kedalaman, seiring dengan bertambahnya kedalaman, pemanasan air oleh sinar matahari akan semakin berkurang. Menurut Nurfitriani, dkk. (2017) perbedaan suhu disebabkan oleh cuaca cerah/panas dan daerah tersebut lapang 
tidak adanya penutupan tumbuhan mangrove sehingga matahari melepaskan panasnya dengan sempurna.

Berdasarkan parameter suhu perairan sungai Jeneberang tergolong dalam mutu baku air minum kelas II PP No. 82 tahun 2001. Kenaikan suhu dapat mempengaruhi plankton. Kisaran suhu optimum bagi pertumbuhan fitoplankton di perairan adalah 20-30 ㄷ (Effendi, 2003). Hal ini berarti, suhu air sungai mampu menunjang pertumbungan fitoplankton. Suhu yang signifikan berpengaruh terhadap kelimpahan fitoplankton kemungkinan terkait dengan intensitas cahaya, yakni kecenderungan meningkatnya suhu mengikuti peningkatan intensitas penyinaran. Oleh karena itu, pengaruh langsung suhu dalam hubungannya dengan metabolisme mungkin relatif lebih rendah jika dibandingkan dengan pengaruh cahaya terhadap fotosintesis yang menyebabkan perubahan pertumbuhan dan kelimpahan fitoplankton. Menurut Alpine dan Cloern (1988) dalam Hatta, et al. (2010), intensitas cahaya merupakan faktor utama yang mengontrol pertumbuhan fitoplankton.

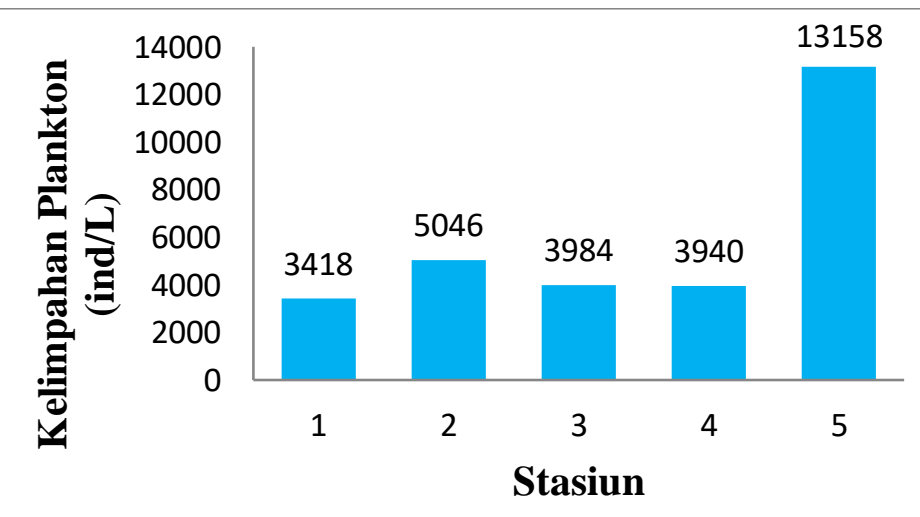

Gambar 7. Rata-rata klimpahan plankton setiap stasiun Sungai Jeneberang

Hasil uji regersi berganda pengaruh eutrofikasi yakni Nitrogen total dan Fosfat secara simultan terhadap kelimpahan
Berdasarkan uji regresi berganda hubungan Eutrofikasi dengan suhu di Sungai jeneberang diperoleh $\mathrm{F}$ hitung lebih kecil dari $\mathrm{F}$ tabel $5 \%$. Hal ini menunjukkan bahwa eutrofikasi tidak memberikan pengaruh terhadap suhu. Koefesien korelasi (R) pada Sungai Jeneberang yaitu 0,319 menunjukkan hubungan variabel bebas $(X)$ terhadap ( $Y$ ) adalah positif rendah. Koefesien determinan $\left(R^{2}\right)=0,102$ menunjukkan ketepatan model tersebut kurang baik karena tidak mendekati $50 \%$, diartikan bahwa pengaruh eutrofikasi yang merupakan variabel bebas terhadap suhu di Sungai Jeneberang yaitu sebesar 10,2 \% dan sisanya sebesar 89,8\% ditentukan oleh faktor-faktor lain yang tidak digunakan dalam analisis ini. Dengan demikian, model ini dapat digunakan dalam pendugaan pengaruh eutrofikasi terhadap kualitas air khusunya suhu dalam sebuah perairan.

\section{Kelimpahan Plankton}

Hasil pengujian kelimpahan plankton di laboratoritum pada aliran Sungai Jeneberang diperoleh kelimpahan antara $3418 \mathrm{ind} / \mathrm{L}$ sampai dengan $13158 \mathrm{ind} / \mathrm{L}$ dapat dilihat pada Gambar 7. 
Tabel 4 Nilai koefisien regeresi, korelasi, koefesien determinan dan uji regresi

\begin{tabular}{|c|r|c|c|c|c|c|}
\hline \multirow{2}{*}{ Variabel } & $\begin{array}{c}\text { Koefesien } \\
\text { Regeresi }\end{array}$ & \multirow{2}{*}{$\mathrm{R}$} & \multirow{2}{*}{$\mathrm{R}^{2}$} & \multirow{2}{*}{$\mathrm{F}$ Hitung } & \multicolumn{2}{|c|}{$\mathrm{F} \mathrm{Tabel}$} \\
\cline { 1 - 2 } Konstanta & 2702,331 & & & & & \\
\cline { 1 - 2 } $\mathrm{X}_{1}$ & 32,854 & 0,186 & 0,035 & 0,394 & 3,44 & 5,719 \\
\cline { 1 - 2 } $\mathrm{X}_{2}$ & $-55,706$ & & & & & \\
\hline
\end{tabular}

Sumber: Hasil Analisis Data Penelitian, 2018

Persamaan regresi kelimpahan plankton pada Sungai Jeneberang yaitu: $y=2702,331+32,854 X_{1}-55,706 X_{2}$

Perubahan kualitas perairan, erat kaitannya dengan potensi perairan terutama ditinjau dari keanekaragaman dan komposisi fitoplankton. Keberadaan plankton di suatu perairan dapat memberikan informasi mengenai kondisi suatu perairan, sehingga plankton sebagai parameter biologi yang dapat dijadikan indikator untuk mengevaluasi kualitas dan tingkat kesuburan suatu perairan. Adanya jenis plankton yang hidup dan blooming karena zat tertentu. Sehingga dapat memberikan gambaran mengenai keadaan suatu perairan yang sesungguhnya (Fachrul, 2005).

Berdasarkan hasil indentifikasi jenis dan kelimpahan pankton pada masingmasing stasiun pada lokasi pengamatan di Sungai Jeneberang menunjukkan bahwa jenis fitoplankton yang ditemukan di stasiun 1 yaitu Rhizosolenia Sp, Coscinodiscus Sp, Bidulphia Sp Peridinium Sp. Stasiun 2 yaitu jenis Coscinodiscus Sp. Stasiun 3 yaitu jenis Rhizosolenia Sp, Coscinodiscus Sp, Bacillaria Sp. Stasiun 4 yaitu jenis Rhizosolenia Sp, Coscinodiscus Sp, Bidulphia Sp. Stasiun 5 yaitu jenis Rhizosolenia Sp, Coscinodiscus Sp, Bidulphia Sp. Sedangkan jenis zooplankton yang ditemukan yaitu Unidentified Larva
Annelida, Unidentified Larva Crustacea, Bivalvia, Temora Sp, Calanus Sp.

Kelimpahan plankton pada Sungai Jeneberang menunjukkan bahwa kelimpahan plankton tertinggi berada pada Stasiun 5 yaitu dengan nilai kelimpahan 13.158 ind/L. Hal ini dikarenakan daerah tersebut banyak mendapat masukan dari luar yang berasal dari pemukiman yang padat sekitar lokasi pengamatan, limbah domestik dan buangan pakan KJA. Kelimpahan terendah terdapat pada stasiun 1 yaitu 3428 ind/L. Pada lokasi ini merupakan daerah hulu yang kandungan nutrisinya lebih sedikit dari kandungan nutrisi yang ada. Kelimpahan yang tidak merata cenderung menyebabkan terdapatnya salah satu jenis fitoplankton yang mendominasi. Hal ini berakibat terjadinya blooming sewaktu-waktu. Jika nutrisi berlebih di perairan tersebut. Secara umum berdasarkan kategori kelimpahan fitoplankton dan zooplankton berdasarkan kesuburan perairan pada lokasi penelitian termasuk dalam perairan mesotrofik atau kesuburannya sedang. Hal ini sesuai dengan pernyataan Raymont (1963) dalam Rahman (2010), yang menyatakan bahwa perairan oligotrofik memiliki kelimpahan fitoplakton antara 0-2000 ind/L dan perairan mesotrofik memiliki kelimpahan fitoplankton yang berkisar antara 200015000 ind/L serta perairan eutrofik 
memiliki kelimpahan fitoplankton $>15000$ ind/L.

Kadar Nitrogen dan Fosfat yang di dapatkan di masing - masing stasiun penelitian cukup tinggi, sehingga plankton memanfaatkan makronurien tersebut untuk mengoptimalkan pertumbuhannya. Tingginya unsur hara tersebut karena adanya kegiatan pertanian di sekitar Sungai Jeneberang sehingga limpasan pupuk pertanian masuk ke badan air yang di bawa oleh aliran air hujan. Sisa - sisa unsure hara dari aktivitas pemupukan, terutama pemupukan urea akan terbawa melalui saluran - saluran irigasi ataupu aliran air hujan. Fosfat merupakan nutrisi yang esensial bagi pertumuhan suatu organisme perairan, Senyawa Fosfat umumnya berasal dari penguraian limbah organik, limbah industri, pupuk, ataupun limbah domestik (Widyastuti et al, 2015). Makarewicz et al. (1998) dalam Hatta (2010) menjelaskan bahwa perubahan kelimpahan relatif fitoplankton menurut ukuran dan komposisi spesies lebih banyak dipengaruhi oleh faktor lingkungan terutama silikat, total Fosfat, dan $\mathrm{N}: \mathrm{P}$, disamping pengaruh beberapa jenis zooplankton.

Berdasarkan uji regresi berganda hubungan Eutrofikasi dengan kelimpahan plankton di Sungai Jeneberang diperoleh $\mathrm{F}$ hitung lebih kecil dari $F$ tabel $5 \%$. Hal ini menunjukkan bahwa eutrofikasi tidak memberikan pengaruh nyata terhadap kelimpahan plankton. Koefesien korelasi (R) pada Sungai Jeneberang yaitu 0,186 menunjukkan hubungan variabel bebas $(X)$ terhadap $(\mathrm{Y})$ adalah positif sangat rendah. Koefesien determinan $\left(R^{2}\right)=0,035$ menunjukkan ketepatan model kurang baik karena kurang dari 50\%, diartikan bahwa pengaruh eutrofikasi yang merupakan variabel bebas terhadap kelimpahan plankton di Sungai Jeneberang yaitu sebesar 3,5 \% dan sisanya sebesar 96,2 \% ditentukan oleh faktor-faktor lain yang tidak digunakan dalam analisis ini. Dengan demikian, model ini sangat dapat digunakan dalam pendugaan pengaruh eutrofikasi terhadap kualitas air khusunya kelimpahan plankton dalam sebuah perairan.

\section{KESIMPULAN}

Berdasarkan uraian pembahasan di atas maka dapat disimpulkan bahwa:

1. Dari analisis Nitrogen total dan Fosfat disungai Jeneberang diperoleh hasil yang menunjukkan bahwa di sungai tersebut telah terjadi eutrofikasi yang menunjukkan bahwa perairan tersebut tergolong kategori subur.

2. Dari analisis kualitas air Sungai Jeneberang meliputi $\mathrm{pH}$, oksigen terlarut, suhu dan plankton masih dalam kategori normal berdasarkan mutu baku air Nomor 82 Tahun 2001

3. Hubungan eutrofikasi terhadap kualitas air meliputi $\mathrm{pH}$, oksigen terlarut, suhu dan kelimpahan plankton diperoleh bahwa eutrofikasi berpengaruh nyata terhadap $\mathrm{pH}$ dan oksigen terlarut di Sungai Jeneberang

\section{DAFTAR PUSTAKA}

Ayyub, F.R., A. Rauf, dan A. Asni. 2018. Strategi Pengelolaan Ekosistem Terumbu Karang di Wilayah Pesisir Kabupaten Luwu Timur. Jurnal Pendidikan Teknologi Pertanian. Vol. 4 Maret Suplemen :S56-S65.

Barus, T.A. 2001. Pengantar Limnologi Studi tentang Ekosistem Sungai dan Danau. Program Studi Biolgi USU FMIPA, Medan, HIm. 5-8. 
Brahmana, S.S., dan A. Firdaus. 2012. Potensi Beban Pencemaran Nitrogen, Fosfat, Kualitas Air, Status Trofik dan Stratifikasi Waduk Riam Kanan. Jurnal Sumber Daya Air. Vol. 8 No. 1: 53-66.

Connel, W.D. dan G.J. Miller, 1995. Kimia dan Ekootoksikologi. Pencemaran. Penerbit: Universitas Indonesia, Jakarta : 520 hal.

Effendi, H. 2003. Telaah Kualitas Air Bagi Pengelolaan Sumber Daya dan Lingkungan Perairan. Yogyakarta: Penerbit Kanisius.

Fachrul, F.M., H. Haeruman, dan L.C. Sitepu. $2005 . \quad K o m u n i t a s$ fitoplankton sebagai bio-indikator kualitas perairan Teluk Jakarta. Makalah. Seminar Nasional MIPA. FMIPA-Universitas Indonesia, Jakarta.

Hariani, D. 2013. Analisis Kandungan Nutrien $(N, P)$ dan Pendugaan Status Kesuburan di Waduk Saguling Jawa Barat. Skripsi. Depertemen Manajemen Sumber Daya Perairan Fakultas Perikanan dan IImu Kelautan. Institut Pertanian Bogor. Bogor.

Hatta, M., Kaswadji, R.F. Purba, dan D.R. Monintja. 2010. Hubungan Antara Kelimpahan Fitoplankton Dan Parameter Lingkungan Di Perairan Pantai Kabupaten Barru, Selat Makassar. Forum Pascasarjana Vol. 33 No. 1

Hidayat, Y. 2001. Tingkat Kesuburan Perairan Berdasarkan Kandungan Unsur Hara $N$ dan $P$ Serta Struktur Komunitas Fitoplankton di Situ
Tonjong, Bojonggede, Kabupaten Bogor, Jawa Barat. Skripsi. Program Studi Manajemen Sumberdaya Perairan. Fakultas Perikanan dan IImu Kelautan.Institut Pertanian Bogor

Irwan, M., Alianto, dan Y.T. Toja. 2017. Kondisi Fisik Kimia Air Sungai Yang Bermuara Di Teluk Sawaibu Kabupaten Monokwari. Jurnal Sumber Daya Akuatik Indopasifik. Vol.1 No. 1.

Kristanto, P. 2004. Ekologi Industri.

Universitas Kristen PETRA Surabaya ANDI. Yogyakarta.

Nur, A.I., H. Syam, dan Patang. 2016. Pengaruh Kualitas Air Terhadap Produksi Rumput Laut (Kappaphycus alvarezii). Jurnal Pendidikan teknologi Pertanian. Vol. 2 No 1: 27-40

Nurfitriani, W. Caronge, dan Ernawati, S. Kaseng. 2017. Keanekaragaman Gastropoda Di Kawasan Hutan Mangrove Alami Di Daerah Pantai Kuri Desa Nisombalia Kecamatan Marusu Kabupaten Maros. Bionature. Vol. 18 No. 1: 71-79.

Nybakken, J.W. 1988. Biologi Laut, Suatu Pendekatan ekologis. Penerjemah: H. Muh. Eidman. Jakarta: PT Gramedia Pustaka.

Patty, S. 2013. Distribusi Suhu, Salinitas Dan Oksigen Terlarut Di Perairan Kema, Sulawesi Utara. Jurnal IImiah Platax. Vol. 1:(3).

Rahman, A. 2010. Penentuan Status Trofik Wadak Koto Panjang Provinsi Riau Berdasarkan Kandugan Klorofil-a Dan Beberapa Parameter Lingkungan. Skripsi. Manajemen Sumber Daya 
Perairan. Fakultas Perikanan dan IImu Kelautan. Institut Pertanian Bogoro. Bogor.

Patang. 2009. Komposisi Spesies, Pola Sebaran Dan Kerapatan Tegakan Vegetasi Padang Lamun (Seagrass Beds.) Di Pesisir Pantai Kabupaten Pangkep. Politeknik Pertanian Negeri Pangkep.

Patang. 2014. Use Of Antibiotic And Probiotic Controlling Water Quality, Growth And Suvival Of Shrimp Lawae Penaeus Monodon Fabricius. Asian Jr. of Microbiol. Biotech. Env. Sc. Vol. 16, No. (2) : 2014 : 241-245.

Putri, F.D.M., E. Widyastuti, dan Christiani. 2014. Hubungan Perbandingan Total Nitrogen dan Total Fosfor dengan Kelimpahan Chrysophyta di Perairan Waduk Panglima Besar Soedriman, Banjarnegara. Scripta Biologica. Vol. 1 No. 1 Maret 2014. Hal. 96-101.

Simbolon, A.R. 2016. Pencemaran Bahan Organik Dan Eutrofikasi Di Perairan Cituis, Pesisir Tangerang. Jurnal ProLife. Vol. 3. No.2.

Silalahi, J. 2009. Analisis Kualitas Air dan Hubungan Dengan keanekaragaman Vegetasi Akuatik di Perairan Danau Toba. Tesis. Sekolah Pascasarjana. Universitas Sumatera Utara. Medan.

Supono. 2008. Analisis Diatom Epipelic Sebagai Indikator Kualitas Lingkungan Tambak Untuk Budidaya Udang. Tesis. Program Pascasarjana. Universitas Diponogoro. Semarang.

Susana, T. 2009. Tingkat Keasaman (pH) dan Oksigen Terlarut Sebagai indikator Kualitas Perairan Sekitar Muara Sungai Cisadane. IImu Laut Vol. 5. No.2. 33-39.

Trisna, H.S., S. Bambang, dan Marsoedi. 2001. Penentuan Status Kulitas Perairan Sungai Brantas Hulu dengan Biomonitoring Makrozoobenthos: Tinjauan Dari Pencemaran Bahan Organik. Jurnal BIOSAIN. Vol. 1: 1-9

Wanna, M., S. Yanto, dan Kadirman. 2017. Analisis Kualitas Air dan Cemaran Logam Berat Merkuri $(\mathrm{Hg})$ dan Timbal (Pb) pada Ikan di Kanal Daerah Hertasning Kota Makassar. Jurnal Pendidikan Teknologi Pertanian. Vol.3. September Suplemen : S197210.

Widyastuti, E., Sukanto, dan S. Nuning. 2015. Pengaruh Limbah Organik terhadap Status Tropik, Rasio N/P serta Kelimpahan Fitoplankton di Waduk Panglima Besar Soedirman Kabupaten Banjarnegara. Biosfera 32 (1).

Yuliastuti, Etik. 2011. Kajian Kualitas Air Sungai Ngringo Karanganyar Dalam Upaya Pengendalian Pencemaran Air. Tesis. Program Magister IImu Lingkungan. Universitas Diponegoro. Semarang. 